\title{
Horse Racing in the United States: A Call for a Harmonized Approach to Anti-Doping Regulation
}

\author{
John T. Wendt
}

The use of performance-enhancing drugs may be the biggest problem facing horse racing in the United States. A 2012 investigation reported that 3,800 horses had tested positive for drugs, the majority for illegal levels of prescription drugs. Additionally, the investigation indicated that approximately 24 horses a week die at America's tracks. The pervasive use of injury-masking and performance-enhancing drugs in United States horse racing has created a crisis in the industry and is destroying the reputation of a once vibrant sport. Because there are 38 separate state racing commissions with different sets of rules and practices, the United States is struggling to reach some sort of harmonization or uniformity. However, recent events have triggered renewed calls for regulation of performance-enhancing drugs. This article addresses what is presently being done to combat the use of performance-enhancing drugs in the "Sport of Kings."

The Triple Crown in horse racing is comprised of the Kentucky Derby, the Preakness Stakes, and the Belmont Stakes. Before American Pharoah accomplished this amazing feat in 2015, the last Triple Crown winner was Affirmed in $1978 .{ }^{1}$ Several horses in the last 10 years have come close. The most notable was a 2014 candidate named California Chrome, who had won the first two legs of the Triple Crown, thereby rising from obscurity to become "America's Horse."2 But going into the Belmont Stakes, Chrome's owner had to get a waiver from the Belmont track stewards to allow the horse to wear nasal strips (similar to the Breath Right ${ }^{3}$ nasal strips worn my humans). ${ }^{4}$ Nasal strips for horses are allowed in Kentucky

\footnotetext{
${ }^{1}$ Triple Crown Races, Triple Crown History (2014), http://www.triplecrownraces.com/.

${ }^{2}$ Tim Wilkin, California Chrome becomes America's horse (May 31, 2014), http://www.sfgate. com/sports/article/California-Chrome-becomes-America-s-horse-5519940.php.

${ }^{3}$ Breathe Right, Instant Nasal Congestion Relief - Nasal Strips (2014), http://www.breatheright. $\mathrm{com} /$.

${ }^{4}$ Canadian Press, Success of California Chrome might lead to anti-doping reform (Jun. 6, 2014), http://www.tsn.ca/other_sports/story/?id=454142.
}

Wendt (jtwendt@ @tthomas.edu) is with the Dept. of Ethics and Business Law, University of St. Thomas, Minneapolis, MN. 
and Maryland but not New York. ${ }^{5}$ The New York Racing Commission, in conjunction with the New York State Gaming Commission and The Jockey Club, issued a statement that nasal strips were not performance enhancing and did pose a welfare or safety risk. 6

The statement made by these three parties exemplifies the current status of regulation in the horse racing industry. The Federal Trade Commission has responsibility, under the 1978 Horse Racing Act, for oversight and enforcement of rules and practices in the sport of horse racing. However, there are at least 38 separate state racing commissions, with 38 different sets of rules and practices in place. ${ }^{7}$ Although recent events and scandals, including California Chrome, have triggered renewed calls for regulation of performance-enhancing drugs,${ }^{8}$ there is no apparent uniformity or harmonization regarding the prohibition against the use of performance-enhancing drugs in the "Sport of Kings." In anti-doping efforts, "harmonization" refers to both a process and an outcome, and has as its focus the World Anti-Doping Code, its sets of international standards and guidelines, and also the UNESCO Convention Against Doping in Sport. ${ }^{9}$

Presently, the use of performance-enhancing drugs may be the biggest problem facing horse racing. A 2012 investigation by The New York Times found that 3,800 horses had tested positive for drugs, the large majority of which were for illegal levels of prescription drugs. ${ }^{10}$ Another Times investigation found that approximately 24 horses a week die at America's tracks, a greater rate than in countries where drug use is severely restricted. ${ }^{11}$ In 2013, Dr. Sheila Lyons, founder of the American College of Veterinary Sports Medicine and Rehabilitation, testified before Congress that, "The pervasive use of injury masking and performance-enhancing drugs in horse racing in the United States has created a crisis in the horse racing industry and

\footnotetext{
${ }^{5} I d$.

${ }^{6}$ New York Racing Commission, Joint Statement From The New York State Gaming Commission, NYRA and The Jockey Club Regarding The Use of Nasal Strips - General News (May 19, 2014), http://www.nyra.com/belmont/joint-statement-from-the-new-york-state-gaming-commissionnyra-and-the-jockey-club-regarding-the-use-of-nasal-strips/.

${ }^{7}$ Ray Paulick, Horse racing back in front of Congress at PA hearing (Apr. 30, 2012), http://www. paulickreport.com/news/ray-s-paddock/horse-racing-back-in-front-of-congress-at-pa-hearingwatch-live-follow-ray/.

${ }^{8}$ Bartlett, Medication Regulations of the California Horse Racing Industry: Are Changes Needed to Prevent the Use of Illegal Drugs?, 27 San Diego Law Review 743.

${ }^{9}$ Barrie Houlihan, Achieving Compliance in International Anti-Doping Policy: An Analysis of the 2009 World Anti-Doping Code, 17 Sport Management Review 265 (2014).

${ }^{10}$ Canadian Press, supra note 4.

${ }^{11}$ Walt Bogdanich et al., Death and Disarray at America's Racetracks (Mar. 24, 2012), http://www. nytimes.com/2012/03/25/us/death-and-disarray-at-americas-racetracks.html?pagewanted=all\&_ $\mathrm{r}=0$.
} 
is destroying the reputation of a once vibrant sport." 12 Even more recently, Travis Tygart, chief executive of the United States Anti-Doping Agency (USADA), said

I've been told that it's the wild, wild West. . . . It's 1,000 times worse than anything we've seen because people in the sport can go out and bet on themselves. Our experience has shown that it's impossible for anyone to both promote a sport and attempt to police the drug issue at the same time. There's a massive conflict of interest." 13

Part I of this article provides a brief general background of efforts to combat doping in sport. Part II provides a brief look at horse racing and anti-doping attempts. Part III discusses the recent doping case concerning Rick Dutrow in the United States. Part IV discusses anti-doping efforts by the International Federation of Horseracing Authorities (IFHA). Part V deals with recent horse racing legislation in the United States and Part VI is the conclusion with recommendations.

\section{General Background of Efforts to Combat Doping in Sport}

Before 1998 there was no coordinated effort to fight doping in sport as each sport had different definitions, policies, sanctions, and punishments. ${ }^{14}$ The 1998 Tour de France cycling scandal highlighted the need for an independent international agency to create unified standards for anti-doping work and to coordinate the efforts of both sports organizations and public authorities. ${ }^{15}$ The independent international agency, the World Anti-Doping Agency (WADA), was created to bring harmony to the international (and national) sporting community with universally accepted rules and protocols. The WADA mission is to lead a collaborative worldwide campaign for doping-free sport. As such, WADA created the World Anti-Doping Code "to advance the anti-doping effort through universal harmonization of core anti-doping elements. It is intended to be specific enough to achieve complete harmonization on issues where uniformity is required, yet general enough in other areas to permit flexibility on how agreed-upon anti-doping principles are implemented."16

\footnotetext{
${ }^{12}$ A Bill To Improve The Integrity and Safety of Interstate Horseracing, and For Other Purposes, Hearing on H.R. 2012, Before the Subcomm. On Commerce, Manufacturing and Trade of the H. Comm. on Energy and Commerce, $113^{\text {th }}$ Cong, 1 - 75 (2013) (statement of Sheila Lyons, DVM, Founder and Director, The American College of Veterinary Sports Medicine and Rehabilitation $\left.{ }^{\circledR}\right)$.

${ }_{13}$ Juliet Macur, Horse Racing Still Stumbling in Antidrug Push (Jun. 3, 2014), http://www.nytimes. com/2014/06/04/sports/horse-racing-still-stumbling-in-push-against-drugs.html?module=Searc h\&mabReward=relbias $\% 3 \mathrm{As} \% 2 \mathrm{C} \% 5 \mathrm{~B} \% 22 \mathrm{RI} \% 3 \mathrm{~A} \% 22 \% 2 \mathrm{C} \% 22 \mathrm{RI} \% 3 \mathrm{~A} 15 \% 22 \% 5 \mathrm{D} \& \_\mathrm{r}=0$.

${ }^{14}$ World Anti-Doping Agency, A Brief History of Anti-Doping (2014), http://www.wada-ama. org/en/about-wada/history/.

${ }^{15} \mathrm{Id}$.

${ }^{16}$ World Anti-Doping Agency, World Anti-Doping Code, 2007 Code Amendments (2007) at 7.
} 
The World Anti-Doping Code unanimously was adopted by all international sports and governments of the world in Copenhagen in March 2003 with 665 signatories binding anti-doping regulation across all continents and sports. ${ }^{17}$ One hundred and seventy-six countries-which equates to 98 per cent of the world's population - have now ratified the UNESCO Convention against Doping in Sport. ${ }^{18}$ However, horse racing is not one of the signatories. The primary problem with horse racing is that many stakeholders either refuse to seek a harmonization of medication standards or deny that there is a problem. ${ }^{19}$

\section{Horse Racing in the United States}

In the United States horse racing is a $\$ 40$ billion industry that generates roughly 400,000 jobs nationwide. ${ }^{20}$ However, the widespread use of performance-enhancing drugs in horse racing threatens the viability, safety, and integrity of the sport. In the 1980s Congress considered banning drugs in horse racing, but ultimately left that decision to individual states. ${ }^{21}$ Yet, there have been recent calls from owners and organizations for Congress to intervene. For example, Arthur B. Hancock III, whose grandfather founded Claiborne Farm, once the home of Secretariat, Mr. Prospector, Danzig, Nijinsky II, Seabiscuit, and the birthplace of more than 75 champions, ${ }^{22}$ has stated

I'm really hoping that we can get Congress's help because drugs have really hurt our sport. ... One trainer uses drugs, even the legal ones, and another feels like he has to do it because "I'm not going to go into a fight with one hand tied behind my back." It's affecting the breed. Now we have chemical horses. We owe it to these noble, beautiful animals to do something. ${ }^{23}$

Ogden Mills Phipps, chairman of The Jockey Club, which is considered by many to be the most influential racing organization in the United States, has been working with the state racing commissions to unify anti-drug efforts. Phipps has stated

\footnotetext{
${ }^{17}$ Matthew Dunn, WADA code strong and dynamic and protecting clean athletes (Jun. 22, 2014), http://www.smh.com.au/sport/wada-code-strong-and-dynamic-and-protecting-clean-athletes20140622-zsi18.html.

${ }^{18} \mathrm{Id}$.

${ }_{19}$ Macur, supra note 13. See also Sid Gustafson, A Solution to Horse Racing's Medication Problems (Jun. 6, 2014), http://www.nytimes.com/2014/06/07/sports/a-solution-to-racingsmedication-problems.html.

${ }^{20}$ Paulick, supra note 7.

${ }^{21}$ Macur, supra note 13.

${ }^{22}$ Clairborn Farm, Clairborn Farm -- 100 Years Doing The Usual Unusually Well (2014), http:// www.claibornefarm.com/.

${ }^{23}$ Macur, supra note 13.
} 
If the major racing states have not implemented these reforms, The Jockey Club will reach out to federal lawmakers who have previously proposed federal legislation for our industry and to other supporters of this approach. We will aggressively seek rapid implementation, including steps leading toward the elimination of all race-day medications. With the safety of our horses, the integrity of competition, and the general perception of the sport all at risk, we cannot afford to wait any longer. Enough is enough. ${ }^{24}$

The federal legislation that Phipps referred to is the Horseracing Integrity and Safety Act. The bill would designate the United States Anti-Doping Agency (USADA) "as the independent anti-doping organization with responsibility for ensuring the integrity and safety of those horse races that are the subject of interstate off-track wagers." ${ }^{25}$ Under the guidelines of the bill, USADA would be responsible to develop within one year rules regarding prohibited substances and methods, testing methods, and the process of adjudicating violations. ${ }^{26}$ As Representative Pitts, who introduced the bill, said, "It's an industry that has, for years, pledged to clean things up. . . . But things seem to be getting worse, not better." 27 If this bill succeeds it would harmonize anti-doping efforts and demonstrate to the public that horse racing takes restoring integrity seriously.

\section{Rick Dutrow and the New York Racing and Wagering Board}

As previously mentioned, horse racing is a multibillion-dollar business - a sport in which an owner or trainer is at considerable financial risk if their horses do not perform better than your rivals. ${ }^{28}$ But to what extent do horse owners and trainers go to ensure that the horse performs at the highest level? The 2008 Kentucky Derby was memorable for two reasons. First, it was won by Big Brown, who became the first horse in 93 years to win the Kentucky Derby after three lifetime races. ${ }^{29}$ The second reason was that runner-up Eight Belles was euthanized on the track immediately

\footnotetext{
${ }^{24}$ The Jockey Club, Statement of Ogden Mills Phipps, Chairman of The Jockey Club and Thoroughbred Owner/Breeder (Mar. 28, 2014), http://www.jockeyclub.com/Default.asp?section=Re sources\&area $=0 \&$ story $=699$.

${ }^{25}$ Brian McCullough, Memorandum Re: Hearing on H.R. 2012, Horseracing Integrity and Safety Act of 2013 (2013).

${ }^{26} \mathrm{Id}$.

${ }^{27}$ Eddie Pells, Lawmaker hopes buzz over California Chrome will spark interest in anti-doping reform (Jun. 6, 2014), http://hosted.ap.org/dynamic/stories/R/RAC_TRIPLE_CROWN_DOPIN $\mathrm{G}$ ?SITE $=$ MABED $\&$ SECTION=HOME\&TEMPLATE=DEFAULT.

${ }^{28}$ Robert Thole, Stop Beating a Dead Horse: How Attempts to Prop Up the Horseracing Industry Have Led to Increased Horse Fatalities, Fewer Bettors, and Less Tax Revenue for Local Governments, 16 Gaming Law Review and Economics 560 (2012).

${ }^{29}$ Joe Drape, Filly's Death Casts Shadow Over Big Brown's Derby Victory (May 4, 2008), http:// www.nytimes.com/2008/05/04/sports/othersports/04derby.html?pagewanted=all\&_r=0.
} 
after the race after breaking her front ankles. ${ }^{30}$ Not only did Eight Belles' death cause controversy, but so did the admission of Big Brown's trainer, Rick Dutrow, that he gave Big Brown the anabolic steroid stanozolol every month. Stanozolol has been in banned in human athletes in both Olympic and professional sports as well as in horse racing in many jurisdictions. ${ }^{31}$ As doping expert Dr. Don Catlin said,

Stanozolol is a long-acting drug, so yeah, it can last a month. . . . If it's there, it's only there, as far as I'm concerned, for doping. But there are people who'll say they need steroids for the general health and benefit of the horse. I just disagree." 32

After the Kentucky Derby, Big Brown went on to win the Preakness. As a result, the champion horse was touted as the would-be winner of the Belmont, thereby completing the Triple Crown of horse racing. Dutrow even said that the outcome of the race was a "foregone conclusion" 33 and "these horses just cannot run with Big Brown." 34 At the Belmont, Big Brown was an overwhelming favorite going off at 3 to 10 odds. ${ }^{35}$ However, not only was the "unbeatable" horse beaten badly, Big Brown pulled up and did not finish the race. ${ }^{36}$ Curiously, Big Brown was not given stanazolol before the Belmont Stakes.

A review of Dutrow's past reveals a lengthy list of violations with numerous racing commissions from 1979 to $2008 .{ }^{37}$ Moreover, Dutrow was either suspended or fined at least once every year from 2000 to 2008 for racing medication violations. ${ }^{38}$ He was suspended in 2009 for giving one of his horses the bronchial dilator clenbuterol. ${ }^{39}$ At the same time, however, Dutrow was also incredibly successful. In 2012, in states where he wasn't banned, horses trained by Dutrow won 40 out of 120 races and placed in the top three finishers 74 per cent of the time. Dutrow

\footnotetext{
${ }^{30} \mathrm{Id}$.

${ }^{31}$ Jerry Bossert \& Christian Reed, Big Brown's legal doping a concern (May 16, 2008), http:// www.nydailynews.com/sports/more-sports/big-brown-legal-doping-concern-article-1.331629.

${ }^{32} \mathrm{Id}$.

${ }^{33}$ Andrew Beyer, The Story Behind Big Brown's Bad Belmont May Never Be Known (Jun. 11, 2008), http://www.washingtonpost.com/wp-dyn/content/article/2008/06/10/AR2008061003041. html.

${ }^{34}$ Pat Forde, Trainer Dutrow eats crow after Big Brown busts at Belmont (Jun. 8, 2008), http:// sports.espn.go.com/espn/columns/story?id=3431608.

${ }^{35} \mathrm{Id}$.

${ }^{36}$ Ray Paulick, Eight Belles, one year later (Apr. 17, 2009), http://sports.espn.go.com/sports/ horse/columns/story?columnist=paulick_ray\&id=4064100.

${ }^{37}$ Ray Paulick, Dutrow's lengthy list of violations (Oct. 13, 2011), http://www.paulickreport. com/news/ray-s-paddock/dutrow-s-lengthy-list-of-violations/.

${ }^{38}$ Bill Finley, Rick Dutrow Says Drug Violation Is Overblown; He Will Appeal (Jun. 28, 2008), http://www.nytimes.com/2008/06/28/sports/othersports/28racing.html.

${ }^{39}$ Jeffrey McMurray, Dutrow suspended 30 days for drug violation (Jul. 7, 2009), http://bleacherreport.com/articles/213591-dutrow-suspended-30-days-for-drug-violation.
} 
was the seventh-ranked horse trainer nationally. ${ }^{40}$ However, in 2011 the New York State Racing and Wagering Board revoked Dutrow's license, which effectively barred him from racing in New York for 10 years. ${ }^{41}$ In addition, Dutrow was fined $\$ 50,000$ for post-race positive violation of one of his horses and the unlicensed possession of hypodermic syringes. ${ }^{42}$ It is believed that Dutrow's suspension and ban is one of the longest in horse racing. Racing and Wagering Board Chairman John Sabini stated,

New York's racing industry has no place or patience for Mr. Dutrow. ... His repeated violations and disregard of the rules of racing has eroded confidence in the betting public and caused an embarrassment throughout the industry. In order to ensure integrity and honesty in the sport of kings in New York, the board acted appropriately in barring Mr. Dutrow from participating. His self-described 'game' in New York horse racing is over. We will not permit individuals who cheat and sully New York's world-class racing product. ${ }^{43}$

Although Dutrow appealed the court found that he had "engaged in conduct that was improper and inconsistent with the public interest and best interests of racing." ${ }^{4}$ The court also found that the 10-year ban and fine were not unconscionable. ${ }^{45}$ Dutrow's subsequent appeal was denied. ${ }^{46}$

\section{International Federation of Horseracing Authorities Attempt at Anti-Doping Regulation}

The International Federation of Horseracing Authorities (IFHA) represents the world's top horse racing bodies with more than 60 member authorities from around the world. Roland Devolz, a veterinarian and technical adviser for the IFHA, spoke on the need for harmonization and anti-doping efforts, saying, "There will be discussion to reach a consensus ... to get anabolics out of training everywhere. As a vet, I believe that racing must be a fair game. If people don't apply the same rule, it is an unfair game." 47

\footnotetext{
40 Sandra McKee, Rick Dutrow's possible 10-year ban viewed as positive by much of horse racing industry (Apr. 9, 2012), http://articles.baltimoresun.com/2012-04-09/sports/bs-spdutrow-0410-20120409_1_racing-commissioners-international-tony-dutrow-laurel-park/1.

${ }^{41}$ New York State Racing and Wagering Board, NYS Racing \& Wagering Board Revokes License of Richard Dutrow, Jr. For Multiple Violations, Assesses \$50,000 in Fines (2011).

${ }^{42} \mathrm{Id}$.

${ }^{43} I d$.

44 Dutrow v. New York State Racing And Wagering Board, 97 A.D.3d 1034, 949 N.Y.S.2d 241 (2012).At 1037

${ }^{45} \mathrm{Id}$.

${ }^{46}$ Dutrow v. New York State Racing And Wagering Board, 19 N.Y.3d 1064 (2012).

${ }^{47}$ Michael Casey, Godolphin scandal raises debate on steroid use (May 2, 2013), http://bigstory. ap.org/article/godolphin-scandal-raises-debate-steroid-use.
} 
Graham Motion, owner of Herringswell Stables and 2011 Kentucky Derby winner Animal Kingdom, stressed the need for the United States to support a harmonized anti-doping effort:

Look, in this day in age, any movement to a medication-free sport is what we need to do. . . . People in America are making excuses why they need medication. I don't buy it. I don't buy the excuses. In America in general, we are constantly looking for a crutch. ${ }^{48}$

Terence S.M. Wan, head of the racing laboratory and chief racing chemist at The Hong Kong Jockey Club recently noted that harmonization and ultimately standardization of anti-doping will facilitate the globalization of horse racing: ${ }^{49}$

Doping and the indiscriminate or inappropriate use of medications are detrimental not only to the integrity of the sport of horse racing but also to the health, welfare, and safety of the racehorses, who cannot refuse such maltreatments themselves. . . . Many doping agents are toxic or produce undesirable adverse effects. The overuse of medications is also harmful and dangerous. Besides doping, the misuse of medications should also be controlled effectively. ${ }^{50}$

Wan went on to note that doping affects the integrity of horse racing and that international collaboration among all stakeholders is necessary. ${ }^{51}$ In fact, the IFHA 2012 Annual Report stressed that from 2012 to 2015, two of the four objectives the IFHA would concentrate on would be harmonization of rules and harmonization of medication control.$^{52}$ In the same report, the IFHA Committee for the Harmonisation (sic) of Raceday Rules emphasized that

It was agreed that for racing to win back fans and customers there was a need to follow the lead of other international sports which play by the same Rules (sic) no matter where in the world that sport takes place. ${ }^{53}$

Most states in the U.S. have statues authorizing commissions with governance of racing. ${ }^{54}$ Similar to the early anti-doping efforts in Olympic sport, organizations are reluctant to relinquish their authority. Thus, one of places in dire need of consistent regulations and harmonization in horse racing is the United States.

\footnotetext{
${ }^{48} I d$.

${ }^{49}$ Christa Leste'-Lasserre, Anti-Doping Regulation Challenges in International Racing (May 17, 2014), http://www.thehorse.com/articles/33891/anti-doping-regulation-challenges-ininternational-racing.

${ }^{50} \mathrm{Id}$.

${ }^{51} I d$.

${ }^{52}$ International Federation of Horseracing, FHA Annual Report 2012 (2013).

${ }^{53} \mathrm{Id}$. at 28.

${ }^{54}$ Bradley Friedman, Oats, Water, Hay, And Everything Else: The Regulation Of Anabolic Steroids In Thoroughbred Horse Racing, 16 Animal Law 123 (2009).
} 


\section{Recent Horse Racing Legislation in the United States}

A recent New York Times investigation found that approximately 24 horses a week die at America's tracks, a greater rate than in countries where drug use is severely restricted. Because there are 38 separate state racing commissions and 38 different sets of rules and practices in place, the United States is struggling to reach some sort of uniformity. Jesse M. Overton, the former Chair of the Minnesota Racing Commission, stated in testimony before Congress,

There is an inherent problem with a model consisting of 38 separate regulatory entities and many industry interest groups all believing they're in charge. The fact is, there is little coordination among racing commissions and industry groups at the state and interstate level. And with so many "cooks in the kitchen," there is confusion, conflicts, and chaos in medication regulation. This is a perfect environment for those who can't keep up with the rules or those who choose to improperly or illegally medicate horses to take advantage of the disorganization. ${ }^{55}$

In 2001, the American Association of Equine Practitioners convened a summit to determine if an agreement could be reached regarding the need for a uniform policy for racehorse medication in the United States. ${ }^{56}$ Out of the conference, the Racing and Medication Testing Consortium (RMTC) was created to develop an industry-wide uniform medication policy statement. ${ }^{57}$ The RMTC is comprised of 25 racing industry stakeholders and organizations that represent Thoroughbred, Standardbred, American Quarter Horse, and Arabian racing. ${ }^{58}$ The RMTC mission is "to ensure the fairness and integrity of racing and the health and welfare of racehorses and participants, and to protect the interests of the racing public." 59 The RMTC is moving forward and has promulgated uniform model rules regarding anabolic steroids that have been adopted by 26 states. ${ }^{60}$ Significantly, in 2008 the RMTC created a Drug Testing Initiative (DTI) Task Force which is aimed at

\footnotetext{
${ }^{55}$ A Bill To Improve The Integrity and Safety of Interstate Horseracing, and For Other Purposes, Hearing on H.R. 2012, Before the Subcomm. On Commerce, Manufacturing and Trade of the H. Comm. on Energy and Commerce, 113 ${ }^{\text {th }}$ Cong. 1 - 6 (2013) (statement of Jesse Overton, Chairman, SkyLearn, LLC and former Chairman, Minnesota Racing Commission)

${ }^{56}$ American Association of Equine Practitioners, Text of Racehorse Medication Summit Report (Jan. 4, 2002), http://www.bloodhorse.com/horse-racing/articles/7399/text-of-racehorse-medication-summit-report.

${ }^{57} I d$.

${ }^{58}$ Hallie Roach, Drug testing task force provide updates (Feb. 12, 2009), http://www.harnesslink. com/News/Drug-testing-task-force-provide-updates-70298?highlight=harmonization.

${ }^{59}$ Racing Medication \& Testing Consortium, RMTC Mission Statement (2013), http://www. rmtcnet.com/content_goals.asp.

${ }^{60}$ Alan Foreman, Racing Medication and Testing Consortium (Aug. 12, 2012), http://www. jockeyclub.com/roundtable_05.asp?section=8.
} 
developing testing standards comparable to those of WADA. ${ }^{61}$ The WADA standards are used by the Fédération Equestre Internationale (FEI), the governing body for equestrian sport. ${ }^{62}$ Dr. Rick Arthur of the California Horse Racing Board said

This is an opportunity to move equine drug testing in this country to a new level. Dr. Don Catlin, founder and former director of the UCLA Olympic Analytical Laboratory, recommended the WADA model for equine drug testing at the Grayson-Jockey Club Welfare and Safety Summit this spring, and he was absolutely correct. We shouldn't settle for less. ${ }^{63}$

In testimony before Congress, equine veterinarian Dr. Sheila Lyons said that the drugs administered were for performance enhancement and to keep horses racing rather than for therapeutic use or concern for its health. Lyons stated, "There was nothing therapeutic about the drugs in that horse. . . They were injury-masking drugs that were stacked." 64

There has been a more recent move to unify anti-doping efforts in horse racing in the United States. In particular, the USADA has become involved in the implementation of anti-doping policies in horseracing. USADA has been considered to be "the last and best hope to return safety and integrity to the troubled sport of thoroughbred racing." ${ }^{65}$ USADA is already responsible for anti-doping efforts in Olympic, Paralympic, and Pan American sport. ${ }^{66}$ Additionally, USADA has worked closely with Major League Baseball and other professional leagues and organizations in anti-doping efforts to eliminate performance-enhancing drugs. ${ }^{67}$

The Horseracing Integrity and Safety Act of 2013, a rare bipartisan bill cosponsored by Rep. Joseph Pitts of Pennsylvania in the House of Representatives ${ }^{68}$ and

${ }^{61}$ Racing Medication \& Testing Consortium, RMTC Board Approves Major Drug Testing Initiative (Sept. 26, 2008), http://www.rmtcnet.com/content_headlines.asp?id=\&s=\&article=427.

${ }^{62}$ Fédération Equestre Internationale, Anti-Doping Rules (2014), http://www.fei.org/content/ anti-doping-rules.

${ }^{63}$ Horsetalk.co.nz, Horse drug-testing to mirror World Anti-Doping Agency (Sept. 30, 2008), http://horsetalk.co.nz/news/2008/09/167.shtml\#axzz35sXF1HHP.

${ }^{64}$ Emily Goddard, FEI Endurance Strategic Planning Group calls on National Federations to approve proposals (Nov. 25, 2013), http://www.insidethegames.biz/sports/summer/ equestrian/1017175-fei-endurance-strategic-planning-group-calls-on-national-federations-toapprove-proposals.11,29]]\}\}\}],"schema":"https://github.com/citation-style-language/schema/ raw/master/csl-citation.json"\}

${ }^{65}$ Joe Drape, Witnesses at Hearing Urge Congress to Enlist Antidoping Agency and Save Horse Racing (Nov. 21, 2013), http://www.nytimes.com/2013/11/22/sports/enlisting-usada-seen-asway-to-restore-faith-in-horse-racing.html?_r=0.

${ }^{66}$ United States Anti-Doping Agency, About: Find out what makes USADA the gold standard in anti-doping (2014), http://www.usada.org/about/.

${ }^{67}$ Joe Drape, Racing Industry Eager to See Bill Allowing Usada Oversight (May 1, 2013), http:// www.nytimes.com/2013/05/02/sports/racing-industry-eager-to-see-bill-allowing-usada-oversight. html?_r=0.

${ }^{68}$ Joseph Pitts, Horseracing Integrity and Safety Act of 2013 (House of Representatives 2013). 
Sen. Tom Udall of New Mexico in the Senate. ${ }^{69}$ The bill would designate USADA as "the authority to permit/prohibit the drugs and medications that may be administered to a horse in a race subject to an interstate off-track wager and set the withdrawal period for its administration." ${ }^{.70}$ Under the legislation, any horse receiving any drug within 24 hours of a race is prohibited from racing. Additionally, race tracks must have an agreement with USADA that includes terms and conditions regarding compliance with rules. ${ }^{71}$ Pitts stressed the need for a uniform approach at least in the United States, saying, "Despite promises and assurances, state and industry groups have been unable to come together to develop uniform rules to police doping. . . . Congress must step in to offer a sound national framework to protect the horses, the riders, and the public." 72 While similar legislation has been proposed in the past, these current bills have garnered more cosponsors than any previous efforts.

Key components of the bill, which may increase its eventual odds of passing in Congress, are as follows. First, no new federal agencies would need to be created. Second, funding would come from the industry through a percentage of the gambling bets or a series of fees from racetracks, horsemen groups, breeders, and owners. ${ }^{73}$ Part of that financing would come from racing associations, who before conducting a race with interstate, off-track betting, must enter into an agreement with USADA and comply with its anti-doping rules. ${ }^{74}$

\section{Conclusion}

There will be struggles and challenges in the process for harmonization in horse racing anti-doping, just as there were struggles and challenges in establishing WADA and adopting the World Anti-Doping Code. There are specific steps that can be taken. First, the International Federation of Horseracing Authorities must make stronger efforts and, as with the Fédération Equestre Internationale, become a signatory to the World Anti-Doping Code. The Code is the fundamental document and framework that harmonizes anti-doping regulations across all sports and public authorities across the world. ${ }^{75}$ As a signatory to the Code, the IFHA would

\footnotetext{
${ }^{69} I d$.

${ }^{70} \mathrm{Id}$.

${ }^{71} I d$.

72 Joe Drape, Despite the Evidence, Trainers Deny a Doping Problem (Nov. 22, 2013), http:// www.nytimes.com/2013/11/23/sports/despite-the-evidence-trainers-deny-a-doping-problem. html?partner=rssnyt\&emc=rss.

${ }^{73}$ Drape, supra note 96.

74 Committee on Energy and Commerce Democrats, H.R. 2012, the "Horseracing Integrity and Safety Act of 2013" (Nov. 21, 2013), http://democrats.energycommerce.house.gov/index. php?q=bill/hr-2012-the-horseracing-integrity-and-safety-act-of-2013.

${ }^{75}$ World Anti-Doping Agency, Q\&A on the Code (2014), http://www.wada-ama.org/en/World-AntiDoping-Program/Sports-and-Anti-Doping-Organizations/The-Code/QA-on-the-Code/.
} 
be required to make sure that IFHA's rules and policies would be in compliance with the mandatory articles and other principles of the Code. ${ }^{76}$

The Racing and Medication Testing Consortium's Drug Testing Initiative (DTI) Task Force, which is developing testing standards comparable to those of WADA, must also be supported by every member and stakeholder. The Drug Testing Initiative's main action point is to continue to work with state racing commissions to produce a "Laboratory Standards Document" which is directly modeled after the WADA Laboratory Standards. ${ }^{77}$ When implemented all horse racing laboratories would become ISO 17025 accredited. ${ }^{78}$ This is the same accreditation process as required by the 32 WADA-accredited laboratories. ${ }^{79}$

At the time of the writing of this article, the $113^{\text {th }}$ Congress (2013-2014) had concluded and the Horseracing Integrity and Safety Act had not passed. However, the bill had gotten farther than any other previous legislation and it appears that the others will introduce it again in the $114^{\text {th }}$ Congress for several reasons. First, USADA, an independent, non-governmental agency that is also a signatory of the World Anti-Doping Code, ${ }^{80}$ is more than up to the task of handling the coordination and harmonization of anti-doping efforts in horse racing in the United States. Moreover, USADA already handles drug testing for the United States Equestrian Federation, the governing body a member of the FEI. ${ }^{81}$ With the same laboratory standards, the horse racing anti-doping rules and testing could be harmonized with anti-doping rules and testing already in place in equestrian sport. As Representative Pitts has said,

Horseracing is a noble sport. It was George Washington's favorite pastime. If the sport isn't going to be clean, then we should question whether the federal government should still be giving it favored treatment. My bill, the Horseracing Integrity and Safety Act, doesn't ask too much of horseracing. It merely requires the sport to treat its athletes with the same care we expect from every other sport. ${ }^{82}$

Some question the need for federal interventions, but as Dr. Gregory Ferraro, Director of the University of California-Davis's Center for Equine Health stated, "While many of us feel that federal rules and regulations are something we want

\footnotetext{
${ }^{76} \mathrm{Id}$.

${ }^{77}$ Racing Medication \& Testing Consortium, RMTC Drug Testing Initiatives Task Force Summary (2010).

${ }^{78} \mathrm{Id}$.

${ }^{79}$ World Anti-Doping Agency, Accreditation Process (2009), http://www.wada-ama.org/en/ Science-Medicine/Anti-Doping-Laboratories/Accreditation-Process/.

${ }^{80}$ United States Anti-Doping Agency, supra note 95.

${ }^{81}$ United States Equestrian Federation, Bylaws of the United States Equestrian Federation (2014).

82 Joseph Pitts, Federal obligation to clean up horse racing (May 2, 2014), http://thehill.com/ blogs/congress-blog/204966-federal-obligation-to-clean-up-horse-racing.
} 
to keep out of our sport, I think in this instance, there is just no way to manage this without it." 83

A second reason to believe a bill will be reintroduced is that the fight against doping in all sports is based on the fundamental assumption that athletes want to compete on a fair and level playing field free of performance-enhancing substances. The fight against doping goes to the very heart and soul of sport; that is, the integrity of sport. But, more importantly it goes beyond the spirit of sport. Travis Tygart, head of USADA, and others have related that the current state of the problems of performance-enhancing drugs in horse racing is similar to the problems cycling had in the 1980s and 1990s. ${ }^{84}$ Out of the dark troubles that cycling encountered came the establishment of the World Anti-Doping Code.

A third reason is, as it has been in cycling as well as other sports, protecting the health and well-being of athletes, both human and equine, is essential. ${ }^{85}$ Doping and misuse of medications threaten the very welfare of the horses. Performanceenhancing drugs also mask injuries and in many cases leads to the inhumane treatment of animals and death on the racetrack. ${ }^{86}$ As such, it is essential that the Horseracing Integrity and Safety Act be passed. It is time to protect the sport of horse racing in the United States by meeting any challenges set forth and seek harmonization.

\footnotetext{
${ }^{83}$ Panel questions drugs in horse racing (July 1, 2012), http://veterinarynews.dvm360.com/panelquestions-drugs-horse-racing.

${ }^{84}$ Travis Tygart, Preserving Your Rights and the Integrity of Competition (Aug. 12, 2012), http:// www.jockeyclub.com/roundtable_12.asp?section=6.

${ }^{85}$ Ed Kane, Panel questions drugs in horse racing (July 1, 2012), http://veterinarynews.dvm360. $\mathrm{com} / \mathrm{dvm} /$ Veterinary+Equine/Panel-questions-drugs-in-horse-racing/ArticleStandard/Article/ detail/781984.

${ }^{86}$ A Bill To Improve The Integrity and Safety of Interstate Horseracing, and For Other Purposes, Hearing on H.R. 2012, Before the Subcomm. On Commerce, Manufacturing and Trade of the H. Comm. on Energy and Commerce, 113 ${ }^{\text {th }}$ Cong. 1 - 75 (2013) (statement of Sheila Lyons, DVM, Founder and Director, The American College of Veterinary Sports Medicine and Rehabilitation) supra note 9 .
} 